\title{
Gender, politics and sugarcane commercialisation in Tanzania
}

\author{
Emmanuel Sulle and Helen Dancer
}

\begin{abstract}
This article explores relationships between state, corporate capital and local stakeholders in the political economy of sugarcane from a gender perspective. The findings, based on empirical research at the site of Tanzania's largest sugarcane producer pre- and post-privatisation, provide insights into the degree to which the estateoutgrower model can be regarded as 'inclusive' for women and men. Three aspects of commercial sugarcane production are analysed: land tenure, labour and leadership within canegrowers' associations. We argue that politico-economic changes in the sector post-privatisation have increased gender differentiation in sugarcane production and consolidated power in the hands of local elites.
\end{abstract}

Keywords: agricultural commercialisation, gender, outgrowing, political economy, sugar, Tanzania

\section{Introduction}

Since privatisation of the African sugar sector in the 1990s, growth in African domestic markets and preferential European Union (EU) trade agreements have generated a surge in production of sugar and ethanol in at least seven southern and east African countries (Dubb, Scoones, and Woodhouse 2017; Dubb 2017). Tanzanian agricultural policy now prioritises large-scale sugarcane production using a model that combines large estates with processing mills, with independent outgrowers supplying their sugarcane to the estate mills under pre-negotiated agreements. This model is considered effective in balancing trade-offs between the interests of rural outgrowers, investors and national development (Woodend 2003). In much of southern Africa, this 'estate-outgrower' model has enabled countries to retain a comparative advantage against the biggest global producer - Brazil (Dubb et al 2017). However, often poor contractual arrangements, coupled with weak national legal and institutional frameworks make outgrowers weaker partners in the agreement (Paradza and Sulle 2015; Matenga 2017; Chinsinga 2017).

Recent research on the changing political economy of sugar in southern and east Africa suggests that the outcomes for outgrowers vary according to context-specific relationships between state, corporate capital and local stakeholders (Dubb et al 2017). Debates on contract farming in this journal and elsewhere point to its transformative impact on power relations within outgrower communities and households. These contractual relationships are said to create dependencies on the agribusinesses that set the 'rules of the game' (Adams et al 2018), tying farmers into arrangements that 
represent 'the antithesis of market forces' (Little 1994, 220) resulting in 'semiproletarianised livelihoods' (Matenga and Hichaambwa 2017). The level of risk to smallholders can be highly dependent on the particular business model used (Cotula 2011) as well as the strength of customary claims to land, which may favour smallholders in the balance of power between contractual actors (Smalley and Corbera 2012; White et al 2012). Within the sugarcane sector as a whole, outcomes have been found to vary within categories of outgrowers, company employees and land-holder or loser, thereby challenging the model's agenda of 'shared growth' and inclusivity (German and Parker 2019). Within the literature on gender and agriculture, it is well established that gender inequalities may be exacerbated by the failure to pay attention to intrahousehold gender dynamics in contractual arrangements (Agarwal 1994, 1997; Behrman, Meinzen-Dick, and Quixumbing 2012; FAO 2011; Schneider and Gugerty 2010), or by exploitative employment conditions in estate agriculture (Mbilinyi 1988; Smalley 2013, 52) and a global trend towards feminisation and casualisation of the workforce (Standing 1989). However, the benefits and losses for women of estate-outgrower arrangements are not uniform (Mate 2001; Oya 2010, 2012; Smalley 2013). The reasons for this variation, and the gender implications of changes in the political economy of sugar have received limited attention in mainstream empirical studies.

Drawing from feminist political economic approaches to the study of land and agricultural commercialisation in Africa (Behrman, Meinzen-Dick, and Quisumbing 2012; Daley 2011; Doss, Summerfield, and Tsikata 2014; Mackintosh 1989; Mbilinyi 1988; Razavi 2003), this article contributes new findings on gender and the political economy of sugar since privatisation in Tanzania. Specifically, it analyses the significance of the local politics of land tenure on women and men's participation in cane outgrowing, the consequences of privatisation on women and men's employment in the sector, and the interplay of gender with other categories of social difference in shaping prospects for local leadership in canegrowing. The paper draws on empirical research conducted by Emmanuel Sulle in Kilombero District, Tanzania between 2013 and 2016 at the site of Tanzania's largest sugar producer - Kilombero Sugar Company Limited (KSCL), and a historical baseline study of gender and sugar production in the same area preprivatisation (Mbilinyi and Semakafu 1995), to present a longitudinal analysis of the relationship between gender, politics and sugarcane commercialisation in Tanzania.

Gender as a social category intersects with age, wealth, ethnicity and other social categories in the operation of social and economic systems, including industries, households and family life (Crenshaw 1989; Dancer and Hossain 2018, 9). The interplay of these social categories shapes the dynamics of local social relations and struggles over resources that produce social differentiation (Berry 1993). While social differentiation in the case study area of Kilombero has been discussed elsewhere (Sulle 2016), Mbilinyi and Semakafu's (1995) baseline data on gender and sugarcane production in Tanzania makes it possible to analyse gender specifically, and the relationship between privatisation and women and men's participation in the estate-outgrower model of canegrowing over time.

The history of the estate-outgrower model in the Kilombero Valley dates back to the early 1960s. The relationship between state and company has changed since privatisation; however, the production arrangement between company and outgrowers has remained largely unchanged, which enables a longitudinal comparison to be made. Mbilinyi and Semakafu (1995) conducted their study before the privatisation of Kilombero Sugar Company in 1998, with the main objective 'to facilitate an increase in the proportion of women in more-skilled, better paid jobs in plantation production and to make more 
employment options available to women in sugar cane plantations' (Mbilinyi and Semkafu 1995, 1). This research encompassed all four of Tanzania's sugarcane companies, including Kilombero Sugar Company. It examined gender differentiation in employment and production processes in the sugar industry, as well as in land tenure and sugarcane outgrowing.

The current findings are based on six fieldwork visits forming part of a wider study of sugarcane production in Kilombero by Emmanuel Sulle between 2013 and 2016, which included 114 key informant interviews of individuals from the private sector, trade union, canegrowers' associations, local and central government, NGOs and academia; 6 focus group discussions with farmers' groups, elders and youth; an initial survey of 60 households focused specifically on gender, and a later survey of 275 households. ${ }^{1}$ Data collected from key informant interviews, household surveys, company statistics and local land registries was triangulated throughout the four years of empirical research. Households for the surveys were selected at random within two villages - Msolwa Ujamaa and Sanje - adjacent to the company itself. Land-holding in each of the villages has a distinct legacy of ujamaa (African Socialism), which is discussed further below.

The first part of the article contextualises the empirical study in a historical overview of the relationship between state, company and community and literature on gender and commercial sugarcane production. The second part presents the empirical findings on gender differentiation: (1) in local land tenure patterns and participation of women and men in outgrowing, (2) in labour and company employment structures, and (3) in the leadership of canegrowers' associations. The results reveal that the legacy of colonial land tenure and patterns of land-holding under ujamaa in the study villages is reflected in canegrowing arrangements between company and community today. On the estate itself, a relative decline in women's permanent employment since privatisation has limited women's employment possibilities. However, the gender differentiating effects of the business model are not uniform for women as a social category, with wealth in terms of land ownership being a significant factor. Within an estate-outgrower arrangement often regarded as an 'inclusive business model', the political economy of sugarcane postprivatisation has increased gender differentiation in sugar production and consolidated power and leadership in the hands of local elites.

\section{The state, capital and privatisation of KSCL}

Sugarcane production in Africa dates back to the nineteenth century when the first plantations were established in the British colony of Mauritius and subsequently in Natal (now South Africa) (Dubb, Scoones, and Woodhouse 2017; Lincoln 2006; Richardson 2010). The expansion of sugarcane production in the rest of southern Africa (mostly of British and Portuguese colonies (Lincoln 2006)) was later facilitated by the British Commonwealth Sugar Agreement, which 'guaranteed fixed prices to historic colonial producers' (Richardson 2010). Colonial and present independent governments, donor agencies and the private sector all supported the expansion of sugarcane farming through the provision of infrastructure, finance and political support (Smalley, Sulle and Malale 2014; Dubb, Scoones, and Woodhouse 2017). In the late 1990s, in southern Africa in particular, most of the former state-owned estates and mills were privatised to foreign capital investment. Business operations of these mills and estates were subsequently restructured through the introduction of cost-shedding mechanisms. These included

\footnotetext{
${ }^{1}$ From 2013 to 2016 Emmanuel Sulle made two trips per year to Kilombero for an average of two weeks per visit. Both authors visited for two weeks in April 2014.
} 
outsourcing most of their operations to other service providers, (Satorius and Kirsten 2004) leaving the production to independent sugarcane producers (outgrowers) (Dubb, Scoones, and Woodhouse 2017; Sulle and Smalley 2015).

Since the colonial period, sugarcane in Africa has been produced largely through two models of production: plantation estates, and a combined plantation estate-outgrower model. Plantation estates are usually managed by large companies with a fully operating factory or factories for processing cane and other by-products. Under this model all activities of production, processing and marketing are carried out by the estate. The estate model is preferred by large corporations and is considered a creditworthy project, in which it is comparatively easy to control quality, quantity and the outbreak of disease (Sulle and Nelson 2009), as well as to secure a supply of labour from rural poor men and women, particularly those without land and other assets. However, it is often difficult to establish an estate in areas of land scarcity and doing so is likely to result in expropriation, displacement and increased pressure on land, water and other resources (Hall, Scoones and Tsikata 2017; Sulle, Smalley and Malale 2014). Moreover, the economic benefits often only flow to a few international company shareholders with relatively limited positive impact on the host country's economy. The number of jobs created by large estates is also often limited, and generally fewer than the number of people directly or indirectly displaced by such investments (Li 2011).

Sugarcane production and its associated businesses are contentious and affected by local, national and international politics of protectionism and liberalisation (Richardson 2010; Bates 1981). Understanding how the state works to achieve the dual and often contradictory goals of political legitimation and capital accumulation in both the local and global economy (Bonal 2003; Klerck and Sycholt 2010) allows an assessment not only of its role in the privatisation of KSCL, but also of how it continues to safeguard the interest of both capital and outgrowers. This section provides an account of the history of sugarcane farming in Kilombero, Tanzania, the role of the state and how the privatisation of KSCL reshaped the relationship between the company and outgrowers.

Sugarcane production in Kilombero Valley started in the early 1920s with small jaggeries (Baum 1968). Large-scale commercial production started in around the 1960s when the then Kilombero Sugar Company (KSC) with funding from the International Finance Corporation, the Commonwealth Development Corporation (CDC), Standard Bank and two Dutch financial organisations, established its first factory in Msolwa area in the 1960s (Baum 1968; Sulle and Smalley 2015). From its inception, KSC ran its estates with outgrowers. This was part of a strategic decision made by one of its funders, the CDC which supported other outgrower schemes including the similar model in Kenya (BuchHansen and Marcussen 1982; Smalley et al 2014).

KSC was later nationalised in 1967 after the implementation of the Arusha Declaration, which saw the government retaking management of industries of high economic value for the nation. The nationalised KSC was placed under the management of the National Food Corporation (NAFCO) and subsequently the Sugar Development Corporation (SUDECO) which took charge in 1974 with core activities of developing the national sugar industry, distribution, exports and imports of sugar. In 1976, KSC built a second sugar factory to expand the company's cane production crushing capacity. This in turn increased both outputs from the company's estates and outgrowers' cane supply to the mills (Kamuzora 2011; Siyao 2012). Throughout this period of state control of KSC, the 
state subsidised extension services to outgrowers as well as cane-cutting and transportation of outgrowers' cane (Interview, outgrower leader, 24 October 2016).

During global structural adjustment programmes of the late 1980s a combination of cuts to state agricultural subsidies, stiff competition in the sugar business and worker demands for better pay, resulted in production and profit falling to the lowest in the company's history (Mbilinyi and Semkafu 1995; Sprenger 1989). Outgrowers' cane supply also fell to its lowest during the period of state control: from 42 to 15 percent in 1978 (Sprenger 1989). Outgrower production did not pick up until the company was privatised in 1998 to South African Company, Illovo Sugar Group which acquired the majority share of 55 percent (Smalley et al 2014). The government of Tanzania maintained the 25 percent share in the company while 20 shares were acquired by ED\&F Man, the UK Commodity Trader. In June 2016 Illovo Sugar Group was purchased by Associated British Foods (Dubb et al 2017). The sale of KSC to South Africa's largest sugar company needs to be viewed against the South African government's support for homebased companies expanding their business across the continent, acting as the conduit for other global interests in agriculture (Hall 2011, 2012; Martiniello 2017).

After taking over the management of KSC, Illovo changed the name to Kilombero Sugar Company Limited (KSCL), embarked on renovating factories, improving its production in sugar estates and mobilising outgrowers by providing cheap loans, maintaining their infrastructure and guaranteeing a market and fixed price (Kamuzora 2011; Martiniello 2017; Smalley, Sulle, and Malale 2014). To date, the company leases about $9562 \mathrm{ha}$ from central government, 8000 ha of which is under sugarcane, with the remaining land used for factories, offices, staff houses and social amenities. (Illovo 2014). It sources the rest of its sugarcane from over 8500 registered outgrowers. The partnership between KSCL and the outgrowers is based on a cane supply agreement (CSA) negotiated and signed by the company and canegrowers' associations every three years. Contract farming arrangements today differ from the 1980s when state-owned parastatals or private firms had contracts with farmers who were supplied with inputs, tractors and extension services to assist their production (Oya 2012). In Kilombero, the contractual arrangement has changed over time, so that today most outgrowers carry out most of their production activities on their own land. Given the nature of the sugar business, outgrowers' incomes are variable. Income may be affected by cheap imports of sugar, variable sucrose levels and other agronomic factors, and by the terms of the contract with the processor.

KSCL's expansion strategy, which includes an outgrowers' scheme, is financed by the government of Tanzania, the EU among other donor agencies, local and international financial institutions and NGOs (Sulle and Smalley 2015; Tomlinson 2005). As a result, both estate and outgrowers' outputs have increased substantially with outgrowers accounting for about 43 percent of total cane processed by the company's mills (Illovo 2014; Sulle 2017). Nonetheless, these increases in productivity must not be attributed to privatisation per se, but to a number of factors at play. The entrance of foreign capital was accompanied by several policy reforms and increased state investment in public services and goods. Three years after KSCL was privatised, the government enacted the Sugar Act of 2001, which restricted cheap sugar imports, raised the price of locally produced sugar and boosted local production. This was followed by the EU's Preferential Trade Agreement which, among other things, ensured that products from least developed countries (LDCs) entered European markets on a duty-free and quota-free basis. As such, further development of sugarcane production in Tanzania needs to be assessed against 
the current EU regulatory reforms in the sugar industry, which ceased the Preferential Trade Agreement on 30 September 2017 (European Commission 2017).

\section{Gender and commercial sugarcane production}

The global economic trend towards liberalisation and increased labour flexibility since the 1980s has brought with it a rise in the participation of women in the labour force, including in commercial agriculture. However, this 'casualisation' and 'feminisation' of the workforce (Standing 1989) has not automatically produced an overall improvement in women's employment prospects in global supply chains. As Kabeer argues, "employment itself has started to take on some of the "informalised" characteristics of work conventionally associated with women' (Kabeer 2003, 65). Global supply chains depend on women's work being undertaken not only as waged employees, but also informally, using visible and hidden labour within households (Dunaway 2014; Dancer and Tsikata 2015,13 ). These changes in systems of commodity production, particularly the shift from food crop to cash crop, have also had significant impacts on household food security and gender relations within households (Carney and Watts 1990; Mbilinyi 2010, 2016; Meinzen-Dick et al 2011; Razavi 2003; Von Bülow and Sørensen 1993; Whitehead 2009). These impacts include changes in the gender division of household labour and access to and control over resources, including land. However, studies focusing on gender emphasise that the effects of agricultural commercialisation on women's farming are not uniform. Local gendered social norms and practices contribute to gender differentiation across different models of commercialisation (Mate 2001; Oya 2010; Smalley 2013). At an individual level, gender differentiating impacts of commercialisation are also shaped by the interactions between gender and other factors of social difference, including wealth, ethnicity, age, education and marital status.

It is well established that in areas of commercial pressure on land, women with limited access to resources tend to lose out in agricultural contracting arrangements (Behrman, Meinzen-Dick, and Qusumbing 2012; FAO 2011; Schneider and Gugerty 2010). This is in part, because the contracting arrangements within outgrowing often entrench preexisting gendered power relations within households as companies contract with household heads and land is converted from household food crops (some of which are sold by women in local markets) to cash crops. A common finding among the studies cited above is that expansion in cash crop production also usually has the effect of increasing women's workloads overall and reducing women's bargaining power within the household where most cash-crop income is retained by men.

Estate agriculture is often associated with labour exploitation and has been shown to have a negative impact on intra-household gender relations, labour patterns and wage inequalities (Mbilinyi 1988; Smalley 2013, 52). In terms of labour exploitation, studies demonstrate that it is often poorer women who have limited livelihood options that represent a 'captive labour pool' for farms and estates (Cramer and Pontara 1998; Hayami 2010; Loewenson 1992; Smalley 2013). The consequences of high levels of mechanisation on women's work have varied according to context. Mechanisation has both increased feminisation of the workforce, and excluded some women from the labour market, depending on the kind of labour that mechanisation has replaced (Dolan and Sorby 2003).

Recent studies of African sugarcane production show mixed results in terms of their implications for gender relations and women's economic power within the household. In Zambia, Richardson (2010) found that in married sugarcane-growing households, both 
men and women enjoyed increased economic stability and improvements in family diets, but existing gender inequalities within the household were unchanged by the institutional arrangements of the company's commercial outgrower model. By comparison, widowed female heads of households experienced greater benefits in terms of increased status and income through their participation in the model, as it was more socially acceptable for them than for married women, to own and manage their own land for sugarcane growing. These findings are supported by studies of irrigation schemes in Mozambique and South Africa, which highlight that an 'efficiency discourse' that opposes the use of irrigated land for subsistence agriculture risks accelerating processes of social and economic marginalisation for poor rural women in particular (Pellizzoli 2009). Similarly, research from Swaziland identifies female-headed households as at a particular risk of increased food insecurity in areas experiencing a swift move towards irrigated sugarcane. In that local context, the shift was accompanied by cessation of cotton and declining maize, beans and sweet potato production (Peter et al 2008).

The impacts of sugarcane commercialisation on estate employment are also highly gender-differentiated. In Mozambique patterns of casualisation have seen employed women workers disproportionately affected by permanent and seasonal job cuts, with a heavy reliance on migrant labour from neighbouring or distant regions for seasonal field work (Lazzarini 2017; 0'Laughlin and Ibraimo 2013). This and other research on Tanzania and Zambia (Mbilinyi and Semakafu 1995; Rocca 2014) reports a masculinising of certain areas of the workforce, particularly cane-cutting. Other field labour, such as weeding, is conventionally associated with women and older men and is less well paid.

This study explores the relationship between the political economy of sugar in Tanzania and gender differentiation in KSCL's estate-outgrower model, in a local agrarian context with a legacy of colonial expropriation of land and ujamaa. There is some debate within the mainstream literature as to whether this estate-outgrower model has been effective for balancing the interests of rural outgrowers, investors and national economic development in Tanzania (Sulle and Nelson 2009). In a 1990 study of gender and teagrowing in the Usambara Mountains of northeastern Tanzania, Sender and Smith then argued that growing social differentiation in rural Tanzania was reinforced by the failure of the ujamaa project. Labour shortages on Tanzania Tea Authority estates were argued to be the result of husbands' control over the labour of their wives. Wage employment on estates and smallholder farms was seen as 'an escape route, a liberation from the most oppressive, and even physically violent, relationships with men' (Sender and Smith 1990, 68). What was needed, they argued, was increasing cash crops to generate foreign exchange through exports. While ujamaa as an overall economic policy has been roundly criticised, our findings in the case study context do not point towards the legacy of ujamaa as the source of increased gender differentiation in women's participation in sugar production today. A lack of local customary ties to land resulting from ujamaa villagisation policies and gender-equal principles of village land allocation, have mitigated some of the most gender-differentiating effects of global capitalism and pressure on local land markets. Gender differentiation in sugarcane production in Kilombero has increased. However, this is better explained as the consequence of privatisation, commercial pressures on land, and burgeoning local land markets, rather than ujamaa. 


\section{Case study: Gender and sugar production in Kilombero District}

The research centred on two adjacent villages close to the company plantation - Msolwa Ujamaa and Sanje. Each village has a distinct history, which has resulted in differences in land tenure patterns between the villages. In Msolwa Ujamaa, prior to the 1960s, most land belonged to a single individual member of the leading Tanzanian African National Union (TANU) party. Some land was given in parcels to a limited number of people to establish a village (Smalley et al 2014; Sulle and Smalley 2015). Other land was later nationalised and became the village farm. As part of ujamaa policies of the 1960s, plots were allocated to both men and women villagers on an equal basis. In contrast to Msolwa Ujamaa, in Sanje today, land tenure shows a marked differentiation between four largescale farms comprising over 500ha, and villager-owned small plots of around 1.5ha (4 acres) (Smalley et al 2014). Originally appropriated by German, Dutch and South African settlers, the large-scale farms were re-acquired by new owners - Tanzanians with Indian and Arabic origins - after the previous owners were ejected by the independent Government of Tanzania (Sulle and Smalley 2015). However, unlike in Msolwa Ujamaa, they were not redistributed or brought under communal control. Ujamaa policies were practiced in Sanje, but not to the same extent as in Msolwa Ujamaa. The inequality in the distribution of land in Sanje between four large-scale farmers and other villagers continues to this day. In the two villages, our findings show that the enduring impact of ujamaa is more apparent in Msolwa Ujamaa than in Sanje, both in terms of access to and control over land (Mbilinyi 2016) and village administrative structures (Greco 2016). Some ujamaa practices have been eroded over time. For instance, villagers no longer work collectively on communally owned farms where they used to share the proceeds of agricultural production, although Msolwa Ujamaa has maintained its village farm and uses the revenue it generates to pay for various social services, medical services, construction and medical staff houses (Interview, Msolwa Ujamaa Village Chairman, 25 October 2016).

\section{Gender and land tenure}

As Mbilinyi (2016) has argued, the long-term outcomes of the implementation of ujamaa villagisation policies are complex and context-specific.

\begin{tabular}{|c|c|c|c|c|c|c|}
\hline & $\begin{array}{l}\text { Man } \\
\text { only }\end{array}$ & $\begin{array}{c}\text { Woman } \\
\text { only }\end{array}$ & $\begin{array}{c}\text { Both (held either jointly } \\
\text { or individually) }\end{array}$ & $\begin{array}{l}\text { Man } \\
\text { only }\end{array}$ & $\begin{array}{c}\text { Woman } \\
\text { only }\end{array}$ & $\begin{array}{c}\text { Both (held either jointly } \\
\text { or individually) }\end{array}$ \\
\hline Purchased & 3 & 0 & 5 & 5 & 3 & 6 \\
\hline Inherited & 5 & 2 & 4 & 5 & 3 & 1 \\
\hline $\begin{array}{l}\text { Allocated by } \\
\text { village for free }\end{array}$ & 4 & 2 & 6 & 3 & 1 & 4 \\
\hline $\begin{array}{l}\text { Rented or } \\
\text { borrowed }\end{array}$ & 2 & 2 & 5 & 3 & 2 & 0 \\
\hline $\begin{array}{l}\text { Settled without } \\
\text { permission }\end{array}$ & 0 & 0 & 0 & 2 & 1 & 1 \\
\hline Other & 1 & 1 & 1 & 2 & 0 & 1 \\
\hline Totals & 15 & 7 & 21 & 21 & 10 & 13 \\
\hline
\end{tabular}

They have also created opportunities for rural women to participate in various economic activities, '... including women's cooperative farms, shops, maize mills and beer halls which provided employment, income, and access to productive property as well as to 
scarce goods during the economic crisis of the late 1970s and early 1980s' (Mbilinyi 2016, 120). In the Kilombero Valley, the historical legacy of allocating equal-sized plots of land to men and women in ujamaa villages, a buoyant local land market and a high proportion of migrants from other regions of Tanzania, has meant that issues of genderdifferentiation often associated with customary land tenure practices have less applicability in the area. Table 1 shows the results of a 2014 survey of modes of acquisition of land by 30 households in each of the two study villages $(n=60)$. Land is acquired in multiple ways within both villages - through purchase, inheritance, allocation by the village, renting, borrowing and by adverse possession. 23 (approximately onethird) of the households acquired land through at least two different modes of acquisition. It was also common for both men and women to own land, whether jointly or individually. The survey results show that in Msolwa Ujamaa, allocation by the village was the most common mode of acquisition for men and women. In Sanje, more households purchased land than by any other means. However, overall, men were twice as likely as women to acquire land in their sole name, whether by purchase, inheritance or allocation by the village (Table 1 ).

There was also gender differentiation in the size of plots. In Msolwa Ujamaa respondents reported the average size of plots owned by individual men as $2.13 \mathrm{ha}$ - more than 0.4 ha (one acre) greater than the average plot size of 1.5 ha held by individual women. By contrast in Sanje, where plot sizes are on average smaller for most villagers, the gender differentiation in average size of land tenure was much less (1.58ha for men, 1.48ha for women). ${ }^{22}$ Overall, the average farm size in Tanzania is 1.2ha (FAO 2018). A key reason for higher than average farm sizes in these villages is the ongoing expansion of canegrowing as a result of market demand and higher prices for sugarcane compared with other crops in the area (Sulle 2017).

There are a number of reasons why gender differentiation in land-holding exists in this area in spite of the legacy of ujamaa. It may be attributable to social norms concerning male ownership of land notwithstanding a lack of historic customary ties; or the consequence of unequal access to resources used to purchase land, where demand for land has increased in local land markets. At the same time, with changes in social attitudes to female land-holding, there is some evidence from focus group discussions with women to suggest that more women are retaining their husbands' land as widows than in the past. Moreover, as canegrowers' associations have proliferated in the area and are subject to harvesting quotas issued by the company, some husbands and wives have registered themselves individually as owners of the land with two different canegrowers' associations as a tactic to maximise the chances of their cane being harvested (Interview, association leader, 17 April 2014).

\section{Labour}

In the study villages, many outgrowers rely on labour beyond their own households and many villagers undertake casual work in sugarcane production, whether for other farmers or for KSCL. Around half of the respondents in the 2014 survey said that their households employed others to assist them with cane cultivation. This type of work was generally preferred over casual opportunities within the company due to the system of payments and relatively lower rates of pay. Mbilinyi and Semakafu (1995) reported

\footnotetext{
${ }^{2}$ Villagers self-declared the size of their plots during the household surveys. While self-declared figures are necessarily approximate, they are supported by interview data on plot sizes obtained from the company and canegrowers' associations.
} 
similar findings prior to privatisation. There are notable differences in the type of work and income of men and women, both for other farmers and for the company. Weeding, pesticide and fertiliser application tasks are undertaken on a casual basis on outgrowers' farms, and on a seasonal or casual basis at KSCL. In both cases, it was widely stated in key informant interviews and survey findings that women and older men do most weeding, whereas men do most of the pesticide and fertiliser work. In Mbilinyi and Semakafu's study, it was also observed that in the early 1990s, both men and women perpetuated gender stereotypes of strong masculine cane-cutters and weaker women and older men as weeders (Mbilinyi and Semakafu 1995).

Employment at KSCL was uncommon among the 215 households surveyed. KSCL reported that in 2013 one-third of its employees were 'local citizens of the country' (Interview with company officials, April 2015). However, the company relied heavily on migrant labour from elsewhere in Tanzania at all levels of the workforce, from seasonal workers to senior management. By comparison with the wages paid on outgrowers' farms, in April 2014 KSCL company statistics showed that wages for work done mostly by women were lower than for work done mostly by men. Wages for weeders, for example, were lower than those for pesticide application and cane-cutting. Weeders working on a seasonal basis of six days per week were paid TZS 5,499.46 (US\$3.4) per day. Those employed on a daily casual basis were paid at a lower rate of TZS 5,118.30 (US\$3) per day. Pesticide application was paid at a rate of TZS 5,875.15 (US\$4) per day for seasonal workers, and TZS 5,679.11 (US\$3.5) for casual daily workers. All of these wages were lower than those paid to cane-cutters working a six-day week, who earned TZS 6435 (US\$4) per day. Mbilinyi and Semakafu reported similar income-differentiation between weeding and cane-cutting in their 1995 study. At first glance the 1992 wage statistics suggest parity between weeders and cane-cutters, with both earning the same basic wage of TZS 134/70 per day along with a bonus scheme for regular attendance and task completion. However, cane-cutters were also able to enhance their wages through an incentive scheme for additional work done above the daily 'task'. There was no additional piece rate wage paid to weeders (Mbilinyi and Semakafu 1995, 5, 73).

Table 2. Longitudinal comparison of employment status in the KSCL workforce by gender.

\begin{tabular}{|c|c|c|c|c|c|c|}
\hline \multirow[b]{2}{*}{ Year } & \multicolumn{2}{|c|}{ Men } & \multicolumn{2}{|c|}{ Women } & \multicolumn{2}{|c|}{ Total } \\
\hline & 1992 & 2013 & 1992 & 2013 & 1992 & 2013 \\
\hline Permanent & $\begin{array}{l}4008 \\
(44 \%)\end{array}$ & $\begin{array}{c}760 \\
(36 \%)\end{array}$ & $\begin{array}{c}495 \\
(64 \%)\end{array}$ & $\begin{array}{c}110 \\
(27 \%)\end{array}$ & $\begin{array}{c}4503 \\
(45 \%)\end{array}$ & $\begin{array}{c}870 \\
(34 \%)\end{array}$ \\
\hline Seasonal & $\begin{array}{l}4861 \\
(52 \%)\end{array}$ & $\begin{array}{l}1259 \\
(59 \%)\end{array}$ & $\begin{array}{c}228 \\
(29 \%)\end{array}$ & $\begin{array}{c}250 \\
(61 \%)\end{array}$ & $\begin{array}{c}5089 \\
(51 \%)\end{array}$ & $\begin{array}{l}1509 \\
(59 \%)\end{array}$ \\
\hline Other non-permanent & $\begin{array}{l}344 \\
(4 \%)\end{array}$ & $\begin{array}{l}117 \\
(5 \%)\end{array}$ & $\begin{array}{c}56 \\
(7 \%)\end{array}$ & $\begin{array}{c}49 \\
(12 \%)\end{array}$ & $\begin{array}{l}400 \\
(4 \%)\end{array}$ & $\begin{array}{l}166 \\
(7 \%)\end{array}$ \\
\hline Total & $\begin{array}{l}9213 \\
(92 \%)\end{array}$ & $\begin{array}{l}2136 \\
(84 \%)\end{array}$ & $\begin{array}{l}779 \\
(8 \%)\end{array}$ & $\begin{array}{c}409 \\
(16 \%)\end{array}$ & 9992 & 2545 \\
\hline
\end{tabular}

Source: 1992 data from Mbilinyi and Semakafu (1995, 68); 2013 data supplied by KSCL Human Resources, April 2014. Per- centage figures for men and women represent the proportion of all men and all women working in each category of employment. Percentages in the vertical total column represent the proportion of the workforce working in each category of employment.

The 2014 company data reveals significant gender differentiation in the employment status and seniority of positions occupied by women and men as employees at KSCL. Table 2 shows that in 2013 the proportion of women in the KSCL workforce was 16 percent. Women comprised 13 percent of permanent staff. At first glance, this compares favourably with the 1992 data, where women comprised eight percent of the total 
workforce and 11 percent of permanent staff. However, as at 2013, only 27 percent of women and 36 percent of men were employed on a permanent basis. This represents a sharp reduction from the 64 percent of 779 female employees and 44 percent of 9213 male employees in 1992. The difference is explained by the relative decline in the number of permanent jobs in favour of seasonal and other non-permanent employment. Between 1992 and 2013, the 64 percent of women employed on permanent as compared with 27 percent on seasonal contracts had almost completely reversed (to 29 and 61 percent respectively), meaning that women have been disproportionately affected by the company's shift from permanent to seasonal employment. Between 1992 and 2014 there was a striking reduction in the number of employees at KSCL, while overall production increased, concurrent with restructuring following privatisation and increased mechanisation in sugarcane production over time. In the 2013 fiscal year KSCL employed a quarter of the number of people it employed in 1992. The biggest reduction has been in the number of staff employed on a permanent basis. A similar trend has been observed elsewhere within sugarcane production in Mozambique (Lazzarrini 2017; O'Laughlin and Ibraimo 2013).

The nature of employment by job level is also gender-differentiated. In 1992 Mbilinyi and Semakafu found that 65 percent of women in permanent employment were hired in administration doing mainly secretarial work, compared to 17 percent of men, meaning men had a wider range of permanent employment opportunities than women. They also noted that it was a stated intention of Kilombero Sugar Company to reduce wage costs by keeping long-term workers on casual, temporary or seasonal terms (Mbilinyi and Semakafu 1995, 70-72). Currently, women continue to be employed largely in semiskilled positions, many as office workers, cleaners or administrators. In 2013, 79 percent of female employees worked in semi-skilled and unskilled positions, as compared with 68 percent of men (Table 3). There is relative gender parity at the first level of line management. However, overall across all levels of skilled work and management men outnumber women by a ratio of 11:1 (243 men (32 percent of men): 23 women (21 percent of women)).

Table 3. Gender-disaggregated data for employment by job level at KSCL in 2013.

\begin{tabular}{lllc}
\hline & Men & Women & Total \\
\hline Senior managers & $42(5.5 \%)$ & $2(1.8 \%)$ & $44(5.1 \%)$ \\
Middle managers & $35(4.6 \%)$ & $2(1.8 \%)$ & $37(4.3 \%)$ \\
First line managers & $85(11.2 \%)$ & $13(11.8 \%)$ & $98(11.3 \%)$ \\
Skilled & $81(10.7 \%)$ & $6(5.5 \%)$ & $87(10 \%)$ \\
Semi-skilled & $417(54.9 \%)$ & $82(74.5 \%)$ & $499(57.4 \%)$ \\
Unskilled & $100(13.2 \%)$ & $5(4.5 \%)$ & $105(12.1 \%)$ \\
Total & 760 & 110 & 870 \\
\hline
\end{tabular}

Source: Data supplied by KSCL Human Resources, April 2014.

Today, as part of its attempt to attract more local women to work for it, the company says that it offers a range of support services for families including job offers for spouses. Permanent employees have housing within the company's compound, schooling, childcare and health facilities and local transport around the factory site. However, despite all these attempts, few women have been employed in more technical positions. 
Both company and Sugar Board of Tanzania officials attributed this to the low proportion of girls studying science subjects in secondary school and higher learning institutions. One company official also commented on families generally being reluctant to relocate to the countryside to enable wives to take up skilled employment opportunities. Where families were separated by work commitments, it was far more common for husbands to live away from the family home for long periods (Interview, company employee, 24 April 2014). Presently, company statistics report that 82 percent of seasonal and temporary workers employed by KSCL are men.

With a workforce in 2014 one-quarter of the size it was prior to privatisation in 1992, the majority of job cuts have been to permanent positions, and the impact on female employees proportionately greater than on men. Across the workforce a disproportionate number of women continue to occupy the lowest paid jobs at KSCL and few reach senior grades. There are many reasons for this. The first stems from the perception that the pool of female skilled labour in the agricultural sector is small. A second is the socially and commercially entrenched gender stereotyping of men and women in different roles within sugarcane production. However, both of these factors were present before privatisation and contributed to gender differentiation at that time. Increased levels of casualisation of the workforce since 1992 are attributable to changes in company policy itself, namely the strategic casualisation of the workforce postprivatisation in favour of seasonal migrant employment. These changes have created employment conditions which are largely only attractive to young men, some of whom leave their families for months at a time in search of livelihood opportunities. However, this company strategy must also be viewed in the context of global structural adjustment policies and commercial attempts to maintain comparative advantage in the national sugar industry in the face of cheap sugar imports.

Gender, wealth and leadership of canegrowers' associations

Since privatisation, in terms of size of farmland, inequality among outgrowers has increased (Sulle 2017). While the number of famers cultivating less than five acres has doubled from 3384 in 2003 to 6320 in 2013, the number of outgrowers cultivating between five and 50 acres has increased from eight in 2003 to 1667 in 2013 (Illovo 2014). This represents a significant shift in resource ownership in the area, consolidating control over land and social power in the hands of a minority of richer farmers, while poorer farmers are shifting to food crop farming further afield (Sulle and Smalley 2015). Increased social differentiation in resource accumulation also represents a barrier to leadership positions within canegrowers' associations and concentrates control in the way cane processing quotas are administered. In the Tanzanian sugarcane sector, outgrowers gain access to processing facilities via canegrowers' associations, each of which are allocated quotas for cane harvesting by the company. The constitutions of canegrowers' associations vary; however, often a higher than average threshold of land ownership - for example ten acres (4ha) - is a prerequisite for leadership positions in associations. It is not unusual for chairpersons of canegrowers' associations to own far in excess of 40ha of land.

Leadership within Kilombero's canegrowers' associations is highly gender differentiated. In April 2014, of the 15 local canegrowers' associations in Kilombero, only Muungano had a female chairperson. This exception is explained by the fact that, in common with other association chairpersons, Muungano's chairperson also owned a substantial acreage of land. In interview, she explained that she had inherited 198 acres of land from her father: 
Even God allows women to own land. I was the only child of my father, so my father gave me all his land. This situation, however, did not go down well with other members of my father's family. Some of them wondered why they were not given the land, but my father was clever. He knew they were not close family, so he left the land to me in writing (Interview, 25 April 2014, translated from Kiswahili).

Although the amount of land she inherited was unusually large, the chairwoman's story that she inherited the land as a daughter and only child is not untypical (Dancer 2015; Odgaard 1999). However, although in this and other interviews with villagers, it was recognised that children of both sexes were entitled to own land, male inheritance of land is still prioritised. Muungano's chairwoman explained that she had already subdivided 49.5 acres of her inherited land among her three children as follows: 15.5 acres for the first born (female), 22 acres for the second born (male) and 12 acres for the last born (female). She added: 'my son now knows everything about farming and harvesting cane, and I am very proud of this because I know he can take care of his own future.' (Interview, 25 April 2014, translated from Kiswahili).

Her decision to start her own canegrowers' association was in response to the difficulties she and other outgrowers had experienced in getting their cane harvested through other associations' quotas. Whenever their cane was left unharvested they accumulated debts as a result. The association began with ten farmers, whom she mobilised and led as the only woman among them. By April 2014 her association's membership had grown from 65 to 284 members, comprising 91 women and 193 men. Although she was the only woman on the Board of Trustees, five out of ten members of the association's council were women. By comparison, Sanje canegrowers' association had 379 members of whom 119 were women. At Msolwa Ujamaa canegrowers' association, of the 956 members in 2014, 456 were women and 494 were men. All executive committee members were men (women had not contested).

Why don't women contest for leadership positions in canegrowers' associations? One male canegrowers' association secretary said this could be due to the working conditions of leadership in sugarcane harvesting. This involves going to the fields at night, as harvesting and loading are done over a 24-hour period. He stated that women were less willing to attend to harvesting cane at night where there is also the risk of emergency cane fires (Interview, association secretary, 9 April 2015). By contrast, Muungano's chairwoman replied that this was a question that she was often asked, but that it was difficult to give a simple answer. She reflected that women need access to capital because canegrowing is capital-intensive. There is also a need for farming education and extension services. She added: 'We must change...we must get away from old views that women cannot do this and that... it is only men who can. Now we need to adopt a new system where we believe women can do it.' (Interview, 25 April 2014, translated from Kiswahili).

In practice leadership within canegrowers' associations requires social and economic capital - whether a large acreage of land, or connections. A woman may become a leader of an association, but it is her wealth that provides the social and economic capital to be respected in the role:

... being a leader with some property makes people putyou into a different class. For example, when I decide to walk around my neighbourhood to attend a funeral or any other social gathering, people in the street will ask me: Where is your car? We know it is only us who deserve to walk. So this kind of societal view often pains me (Pers 
Comm. Chairwoman, Muungano Cooperative Society, 28 February 2019, translated from Kiswahili).

However, the wealth a woman needs in order to lead an association can also create tensions within the household if gender norms of control over resources between husband and wife are displaced. As Muungano's chairperson acknowledged, in order to preserve harmony within the marriage, a wife with greater resources than her husband needs to exercise discretion in her use of resources in order to show her respect for him.

\section{Conclusions}

This article has explored relationships between state, corporate capital and local stakeholders in the political economy of sugar from a gender perspective. In doing so, it has addressed the relative paucity of empirical research on gender in mainstream studies of the African sugarcane sector, by analysing the relationship between privatisation and women and men's participation in the 'estate-outgrower' model of sugarcane production over time. The findings generate new insights into the degree to which the model can be regarded as 'inclusive' for women and men, thereby contributing to debates on the estate-outgrower model in developing countries, and the claim that it creates jobs and a win-win situation for private firms and contracted farmers, or outgrowers (Glover 1984; Kirsten and Sartorius 2002; World Bank 2007). It also reinvigorates the debates over gendered power relations and social differentiation often associated with contract farming (Cousins 2013; Scoones et al 2016).

As discussed elsewhere in the literature, the outcomes for outgrowers identified in this study are context-specific and shaped by local land tenure patterns, the particular contractual model and dynamics of the wider political economy (Cotula 2011; Dubb, Scoones, and Woodhouse 2017; Smalley and Corbera 2012; White et al 2012). Our findings on local land tenure patterns demonstrate a clear relationship between gender, wealth and social differentiation in outgrowing. Women's participation as registered outgrowers is generally greater in places where land was historically more equally distributed to villagers of both sexes during and after the implementation of ujamaa policies. Other factors that have proved favourable to women's land tenure in the area include relatively weak customary ties over the land following villagisation, and more recent awareness-raising of women's land rights as part of local land tenure formalisation processes. Yet, there is still significant gender differentiation in land tenure, with men twice as likely as women to acquire land in their sole name in the study villages. This is better explained as the consequence of privatisation, commercial pressures on land, and burgeoning local land markets rather than ujamaa, notwithstanding its reported failings as a national economic policy (Sender and Smith 1990).

The effects of privatisation of KSCL in 1998 on the opportunities for women and men's participation in the 'estate-outgrower' model mirror trends of elite capture of land for agriculture, casualisation and gender differentiation in the workforce observed in commercial agriculture and sugarcane production elsewhyere (Lazzarrini 2017; O'Laughlin and Ibraimo 2013). One of the most significant gender-differentiating outcomes since privatisation found here is the relative decline in women's permanent employment by comparison with men. This reflects an overall casualisation of the workforce since privatisation, which has disproportionately affected women; and a limiting of women's employment possibilities, with men outnumbering women by a ratio of 11:1 in skilled and managerial work in 2013. This gender differentiation may be attributable to societal perceptions of women in science as well as the employment 
conditions associated with seasonal work, which currently depend heavily on migrant labour and are therefore generally unsuited to women with family responsibilities. More could be done by the state and the agricultural sector to promote opportunities for women in agriculture both in terms of creating educational opportunities and challenging entrenched discriminatory views on women in science. However, in order to make employment within the sector a realistic and attractive prospect for both men and women, the company would need to invest more in permanent employment positions so that families were not forced to separate to undertake casualised seasonal work. Given the trend towards casualisation and lower paid work, it is perhaps unsurprising that both men and women who held land for canegrowing in the study villages expressed a preference for outgrowing over working as employees for the company. This is a finding shared by other recent studies where outgrowers reportedly earned more by working their own land than as wage labourers on plantations (Deininger and Byerlee 2011; Li 2011, 285).

The presence of women in leadership roles is an important factor for ensuring women's participation in commercial agriculture more generally. However, currently very few women occupy leadership positions in canegrowers' associations. This gender differentiation is maintained and reinforced by a concentration of social and economic power through land tenure in the hands of wealthier farmers, with richer farmers accumulating more land and increasing their production shares. Women on average hold less land than men and are largely excluded from leadership positions in canegrowers' associations by minimum criteria for selection based on land ownership.

At a national level the estate-outgrower model is touted as one which improves opportunities for smallholder farmers to participate in commercial agricultural production. However, elite capture in an area of pressure on land and consolidation of power in the hands of wealthier association leaders, has the consequence of disadvantaging poorer farmers in getting their cane harvested under quotas and marginalising women farmers in particular. Within company employment structures, sectoral reforms have disproportionately impacted upon women. Their employment possibilities have been limited by systemic factors associated with casualisation and societal gender biases concerning women and men's roles in sugarcane production. The intersection of gender norms with wealth inequalities and wider political-economic changes means that gender differentiation in commercial sugar production has not only been re-entrenched since privatisation, but is deepening.

\section{Acknowledgements}

The authors wish to thank the many individuals who assisted them in their fieldwork in Kilombero and Dar es Salaam, including the villagers and leaders of Msolwa Ujamaa and Sanje villages, representatives and employees at Kilombero Sugar Company Limited, the Kilombero branch of the Tanzania Plantation and Agriculture Workers' Union, the Sugar Board of Tanzania, Kilombero outgrowers' associations and local government officials from Morogoro Regional Commissioners' Office and Kilombero District Council who granted permission for the conduct of the research. Special thanks are due to our co-researcher in the field, Rebecca Smalley, to our field assistants Lameck Malale and Prisca Peter Kiganza; and to Ruth Hall, Marjorie Mbilinyi, Katherine Snyder and Elizabeth Harrison for their valuable comments during the research process. We are grateful to Faustin Maganga and the University of Dar es Salaam for facilitating our fieldwork. We thank the anonymous reviewers and journal editor for their valuable comments on an earlier version of this article. This article draws upon the authors' preliminary findings published in an 
earlier Future Agricultures working paper Gender implications of agricultural commercialisation: The case of sugarcane production in Kilombero District, Tanzania (Future Agricultures, 2015).

\section{Disclosure statement}

No potential conflict of interest was reported by the authors.

\section{Funding}

The fieldwork for this research was supported by the Future Agricultures Consortium, funded by the Department for International Development UK. Emmanuel Sulle received additional PhD scholarships from Council for the Development of Social Science Research in Africa (CODESRIA), PhD Small Grant (CODESRIA), Doctoral Student Resarch Fellowship with Evidence for Policy Design (EPoD) at Harvard University PhD Fellowship and IFMR LEAD and the Danish Ministry of Foreign Affairs for the Hierarchies of Rights: Land and Natural Resource Investments in Africa Research Programme co-implemented by the University of Dar es Salaam, Eduardo Mondlane and Roskilde University.

\section{Notes on contributors}

Emmanuel Sulle is a research associate and $\mathrm{PhD}$ Candidate at the Institute for Poverty, Land Agrarian Studies, University of the Western Cape, South Africa. His research focuses on the politics of inclusive business models in land-based investments, land tenure and rural livelihood. Email: esulle@plaas.org.za.

Helen Dancer is lecturer in law and AHRC leadership fellow at the University of Sussex. Her research interests centre on human-Earth relationships, gender and justice. She is the author of Women, Land and Justice in Tanzania (James Currey, 2015). Email: $\underline{\text { H.E.Dancer@sussex.ac.uk. }}$

\section{References}

Adams, T., J.-D. Gerber, M. Amacker, and T. Haller. 2018. "Who Gains from Contract Farming? Dependencies, Power Relations, and Institutional Change." Journal of Peasant Studies doi: 10.1080/03066150.2018.1534100.

Agarwal, B. 1994. A Field of One's Own: Gender and Land Rights in South Asia. Cambridge: Cambridge University Press.

Agarwal, B. 1997. "'Bargaining' and Gender Relations: Within and Beyond the Household." Feminist Economics 3(1): 1-51.

Bates, R. 1981. Markets and States in Tropical Africa: The Political Basis of Agricultural Policies. California: University of California Press.

Baum, E. 1968. "Land Use in the Kilombero Valley: From Shifting Cultivation Towards Permanent Farming." In Smallholder Farming and Smallholder Development in Tanzania: Ten Case Studies, edited by H. Ruthenberg, 21-50. Munich: Weltforum Verlag.

Behrman, J., R. Meinzen-Dick and A. R. Quisumbing. 2012. "The Gender Implications of Large-Scale Land Deals." Journal of Peasant Studies 39 (1): 49-79.

Berry, S. 1993. No Condition is Permanent: The Social Dynamics of Agrarian Change in SubSaharan Africa. Madison WI: University of Wisconsin Press. 
Bonal, X. 2003. "The Neoliberal Educational Agenda and the Legitimation Crisis: Old and New State Strategies." British Journal of Sociology of Education 24 (2): 159-175.

Buch-Hansen, M. and Marcussen, H.S. 1982. "Contract Farming and the Peasantry: Cases from Western Kenya." Review of African Political Economy 9 (23): 9-36.

Carney, J. and M. Watts. 1990. "Manufacturing Dissent: Work, Gender and the Politics of Meaning in a Peasant Society." Africa 60 (2): 207-241.

Chinsinga, B. 2017. "The Green Belt Initiative, Politics and Sugar Production in Malawi." Journal of Southern African Studies 43(3): 501-515

Cotula, L. 2011. Land Deals in Africa: What is in the Contracts? London: International Institute for Environment and Development.

Cousins, B. 2013. "Smallholder Irrigation Schemes, Agrarian Reform and 'Accumulation from Above and from Below' in South Africa." Journal of Agrarian Change 13 (1): 116-139.

Cramer, C. and N. Pontara. 1998. "Rural Poverty and Poverty Alleviation in Mozambique: What's Missing from the Debate?" Journal of Modern African Studies 36 (1): 101138.

Crenshaw, K. 1989. "Demarginalizing the Intersection of Race and Sex: A Black Feminist Critique of Antidiscrimination Doctrine, Feminist Theory and Antiracist Politics." University of Chicago Legal Forum 1989: 139-167.

Daley, E. 2011. Gendered Impacts of Commercial Pressures on Land. Rome: International Land Coalition.

Dancer, H. 2015. Women, Land and Justice in Tanzania. Woodbridge: James Currey.

Dancer, H. and N. Hossain. 2018. Social Difference and Women's Empowerment in the Context of the Commercialisation of African Agriculture. Working Paper 8. Brighton: Agricultural Policy Research in Africa.

Dancer, H. and D. Tsikata. 2015. Researching Land and Commercial Agriculture in SubSaharan Africa with a Gender Perspective: Concepts, Issues and Methods. Working Paper 132. Brighton: Future Agricultures Consortium.

Deininger, K. and D. Byerlee. 2011. Rising Global interest in Farmland: Can it Yield Sustainable and Equitable Benefits? Washington DC: World Bank.

Dolan, C. S. and K. Sorby. 2003. Gender and Employment in High-Value Agriculture Industries. Agricultural and Rural Development Working Paper 7. Washington, DC: World Bank.

Doss, C., G. Summerfield and D. Tsikata. 2014. "Land, Gender and Food Security." Feminist Economics 20 (1): 1-23.

Dubb, A. 2017. "Interrogating the Logic of Accumulation in the Sugar Sector in Southern Africa." Journal of Southern African Studies 43 (3): 471-499.

Dubb, A., I. Scoones and P. Woodhouse. 2017. "The Political Economy of Sugar in Southern Africa - Introduction." Journal of Southern African Studies 43 (3): 447-470.

Dunaway, W.A. 2014. "Bringing Commodity Chain Analysis Back to its World Systems Roots: Rediscovering Women's Work and Households." Journal of World Systems Research 20 (1): 64-81. 
European Commision. 2017. Fact Sheet: The End of the Sugar Production in the EU. Brusells: European Commision

FAO 2018. Smallholders Dataportrait. Family Farming Knowledge Platform: http://www.fao.org/family-farming/data-sources/dataportrait/farm-size/en/.

FAO 2011. The State of Food and Agriculture 2010-11. Women in Agriculture: Closing the Gender Gap for Development. Rome: Food and Agriculture Organization.

German, L.A., and L. Parker. 2019. "The Social Construction of "Shared Growth": Zambia Sugar and the Uneven Terrain of Social Benefit." Journal of Agrarian Change 19 (1): 181-201.

Glover, D. J. 1984. "Contract Farming and Smallholder Outgrower Schemes in LessDeveloped Countries." World Development 12 (11): 1143-1157.

Greco, E. 2016. "Village Land Politics and the Legacy of Ujamaa." Review of African Political Economy 43 (Supl.1): 22-40.

Hall, R. 2011. "Land grabbing in southern Africa: the many faces of the investor rush." Review of African Political Economy 38 (128): 193-214.

Hall, R. 2012. "The next Great Trek? South African commercial farmers move north." Journal of Peasant Studies, 39 (3-4): 823-843.

Hall, R., I. Scoones, and D. Tsikata. 2017. "Plantations, Outgrowers and Commercial Farming in Africa: Agricultural Commercialisation and Implications for Agrarian Change." Journal of Peasant Studies 44 (3): 515-537.

Hayami, Y. 2010. "Plantations Agriculture." In Handbook of Agricultural Economics, Volume 4, edited by P. Pingali and R. Evenson, 3305-3322: Amsterdam: Elsevier.

Illovo. 2014. (Illovo Sugar Ltd). Integrated Report 2013: www.illovosugar.co.za/Financial/Annual_Reports/Annual_Report2013.aspx

Kabeer, N. 2003. Gender Mainstreaming in Poverty Eradication and the Millennium Development Goals. London: Commonwealth Secretariat/IDRC/CIDA.

Kamuzora, A.K. 2011. "Contractual Governance in Agro-Industry Institutions in Tanzania: A Case Study Analysis." PhD thesis., University of Groningen: http://dissertations.ub.rug.nl/faculties/jur/2011/a.k.n.kamuzora/.

Kirsten, J., and K. Sartorius. 2002. "Linking Agribusiness and Small-Scale Farmers in Developing Countries: Is there a New Role for Contract Farming?" Development Southern Africa 19 (4): 503-529.

Klerck, G. \& M. Sycholt. 2010. "The State and Labour Relations: Walking the Tightrope between Corporatism and Neo-liberalism." In State, Society and Democracy: A Reader in Namibian Politics (2nd edition), edited by C. Keulder, 200-236: Windhoek: Macmillan.

Lazzarini, A.H. 2017. "Gendered Labour, Migratory Labour: Reforming Sugar Regimes in Xinavane, Mozambique." Journal of Southern African Studies 43 (3): 605-623.

Li, T.M. 2011 “Centering Labor in the Land Grab Debate." Journal of Peasant Studies 38(2): 281-98.

Lincoln, D. 2006. "The Historical Geography of the Southern African Development Community's Sugar Protocol." Illesilmperis 9: 117-30. 
Little, P.D. 1994. "Contract Farming and the Development Question." In Living Under Contract: Contract Farming and Agrarian Transformation in Sub-Saharan Africa, edited by P.D. Little, and M. Watts, 216-247: Madison: University of Wisconsin Press.

Loewenson, R. 1992. Modern Plantation Agriculture: Corporate Wealth and Labour Squalor. London: Zed Books.

Mackintosh, M. 1989. Gender, Class and Rural Transition: Agribusiness and the Food Crisis in Senegal. London: Zed Books.

Martiniello, G. 2017. “'Don't Stop the Mill': South African Capital and Agrarian Change in Tanzania." Third World Thematics 1 (5): 633-652.

Mate, R. 2001. "Land, Women and Sugar in Chipiwa." In Women, Men and Work: Rural Livelihoods and South-Eastern Zimbabwe, edited by P. Hebinck and M. Bourdillon, 37-59: Harare: Weaver Press.

Matenga, C. 2017. "Outgrowers and Livelihoods: The Case of Magobbo Smallholder Block Farming in Mazabuka District in Zambia." Journal of Southern African Studies 43(3): 551-566.

Matenga, C.R. and M. Hichaambwa. 2017. "Impacts of Land and Agricultural Commercialisation on Local Livelihoods in Zambia: Evidence from Three Models." Journal of Peasant Studies 44 (3): 574-593.

Mbilinyi, M. 1988. “Agribusiness and Women Peasants in Tanzania." Development and Change 19: 549-583.

Mbilinyi, M. 2010. "Sweet and Sour: Women Working for Wages on Tanzania's Sugar Estates." In How Africa Works: Occupational Change, Identity and Morality, edited by D. F. Bryceson, 51-73: Rugby: Practical Action Publishing.

Mbilinyi, M. 2016. "Analysing the History of Agrarian Struggles in Tanzania from a Feminist Perspective." Review of African Political Economy 43 (sup1): 115-129.

Mbilinyi, M. and A. M. Semakafu. 1995. Gender and Employment on Sugar Cane Plantations in Tanzania. Sectoral and Working Discussion Papers, Agriculture, SAP 2.44/WP.85. Geneva: International Labour Organization.

Meinzen-Dick, R., Quisumbing, A., Behrman, J., Biermayr-Jenzano, P., Wilde, V., Noordeloos, M., Ragasa, C., and Beintema, N. 2011. Engendering Agricultural Research, Development and Extension. Washington, DC: International Food Policy Research Institute.

Odgaard, R. 1999. The Scramble for Women's Land Rights in Tanzania, Researching Development. Quarterly Newsletter from the Centre for Development Research, Copenhagen.

O'Laughlin, B. and Y. Ibraimo. 2013. The Expansion of Sugar Production and the Well-Being of Agricultural Workers and Rural Communities in Xinavane and Magude. IESE Caderno N.o 12E/2013.

Oya, C. 2010. Rural Inequality, Wage Employment and Labour Market Formation in Africa: Historical and Micro Level Evidence. Working Paper 97, Policy Integration Department. Geneva: International Labour Office. 
Oya, C. 2012. "Contract Farming in Sub-Saharan Africa: A Survey of Approaches, Debates and Issues." Journal of Agrarian Change 12 (1): 1-33.

Paradza, G. and E. Sulle. 2015. "Agrarian Struggles over Resources: Insights from two Sugarcane Plantations in Mozambique." In Africa's Land Rush: Implications for Rural Livelihoods and Agrarian Change edited by R. Hall, I. Scoones and D. Tsikata, 150-161, Oxford: James Currey.

Pellizzoli, R. 2009. "Gender, Agriculture and the "Efficient Producer" Discourse: A Case Study from Mozambique, and Lessons from South Africa." Paper presented at the FAO-IFAD-ILO workshop on Gaps, Trends and Current Research in Gender Dimensions of Agricultural and Rural Employment: Differentiated Pathways out of Poverty, Rome, March 31 - April 2.

Peter, G., N. O. Simelane, and J. I. Matondo, 2008. "Socioeconomic Impacts of Small-Scale Irrigation Schemes on Women in Swaziland." Physics and Chemistry of the Earth 33: 850-858.

Razavi, S. 2003. "Introduction: Agrarian Change, Gender and Land Rights." Journal of Agrarian Change 3 (1-2): 2-32.

Richardson, B. 2010. "Big Sugar in Southern Africa: Rural Development and the Perverted Potential of Sugar/Ethanol Exports." Journal of Peasant Studies 37 (4) 917-938.

Rocca, V. 2014. The Gendered Implications of the Expansion in Commercial Sugarcane Production: A Case Study of Contract Farming in Magobbo, Zambia. MA thesis., Carleton University.

Satorius, K. and J. Kirsten. 2004. "The Boundaries of the Firm: Why do Sugar Producers Outsource Sugarcane Production." Management Accounting Research 16: 81-99.

Schneider, K. and M. K. Gugerty. 2010. Gender and Contract Farming in Sub-Saharan Africa: Literature Review. Evans School of Public Affairs, Washington DC: University of Washington.

Scoones, I., B. Mavedzenge, and F. Murimbarimba. 2016. "Tobacco, Contract Farming, and Agrarian Change in Zimbabwe." Journal of Agrarian Change 18 (1): 22-42.

Sender, J. and S. Smith. 1990. Poverty, Class and Gender in Rural Africa: A Tanzanian Case Study. New York: Routledge.

Siyao, P.O. 2012. Barriers in Accessing Agricultural Information in Tanzania with a Gender Perspective: Case Study of Small-Scale Sugarcane Growers in Kilombero District. Electronic Journal of Information Systems in Developing Countries 51 (6): 1-19.

Sprenger, E.L.M. 1989. Sugarcane Outgrowers and Kilombero Sugar Company in Tanzania. Nijmegen: Third World Centre.

Smalley, R. 2013. Plantations, Contract Farming and Commercial Farming Areas in Africa: A Comparative Review. Working Paper 55. Brighton: Future Agricultures Consortium.

Smalley, R., and E. Corbera. 2012. "Large-scale Land Deals from the Inside Out: Findings from Kenya's Tana Delta.” Journal of Peasant Studies 39 (3\&4): 1039-1075. 
Smalley, R., E. Sulle and L. Malale. 2014. The Role of the State and Foreign Capital in Agricultural Commercialisation: The Case of Sugarcane Outgrowers in Kilombero District, Tanzania. Working Paper 106, Brighton: Future Agricultures Consortium.

Standing, G. 1989. “Global Feminization through Flexible Labour.” World Development 17 (7): 1077-95.

Sulle, E. 2017. "Social Differentiation and the Politics of Land: Sugar Cane Outgrowing in Kilombero, Tanzania." Journal of Southern African Studies 43 (3): 517-533.

Sulle E., R. Smalley, and L. Malale. 2014. Opportunities and Challenges in Tanzania's Sugar Industry: Lessons for SAGCOT and the New Alliance. Policy Brief 76, Brighton: Future Agricultures Consortium and PLAAS.

Sulle, E. and F. Nelson. 2009. Biofuels, Land Access and Rural Livelihoods in Tanzania. London: International Institute for Environment and Development.

Sulle, E. and R. Smalley. 2015. "The State and Foreign Capital in Agricultural Commercialization in Tanzania: The Case of Kilombero Sugar Company." In Africa's Land Rush: Implications for Rural Livelihoods and Agrarian Change, edited by R. Hall I. Scoones, and D. Tsikata, 114-31. Oxford: James Currey.

Tomlinson, D. 2005. "Social Development through Outgrower Schemes: The Private Sector Kilombero Business Linkage Program." Paper presented at the Partners for Africa Policy Dialogue Conference, Dar es Salaam, June 22-24. www.partners4africa.org/docs/S2-9-PfA-Tanzania-Tomlinson-Illovo.pdf.

Vaughan, A. 1991. "Cane, Class and Credit: Small Growers in the Glendale Mill Area." Antipode 23 (1): 172-184.

Von Bülow, D. and A. Sørensen. 1993. "Gender and Contract Farming: Tea Outgrower Schemes in Kenya." Review of African Political Economy 20 (56): 38-52.

Von Maltitz, G.P., G. Henley, M. Ogg, P.C. Samboko, A. Gasparatos, M. Read, F. Engelbrecht, and A. Ahmed. 2018. "Institutional Arrangements of Outgrower Sugarcane Production in Southern Africa." Development Southern Africa doi: 10.1080/0376835X.2018.1527215

Matenga, C.R. and M. Hichaambwa. 2017. "Impacts of Land and Agricultural Commercialisation on Local Livelihoods in Zambia: Evidence from Three Models." Journal of Peasant Studies 44 (3): 574-593.

White, B., S. M. Borras Jr., R. Hall, I. Scoones, and W. Wolford. 2012. "The New Enclosures: Critical Perspectives on Corporate Land Deals." Journal of Peasant Studies 39 (3\&4): 619-647.

Whitehead, A. 2009. "The Gendered Impacts of Liberalization Policies on African Agricultural Economies and Rural Livelihoods." In The Gendered Impacts of Liberalization: Towards "Embedded Liberalism"? edited by S. Razavi, 37-62, New York, NY: Routledge.

Woodend, J. 2003. Potential of Contract Farming as a Mechanism for the Commercialisation of Smallholder Agriculture: The Zimbabwe Case Study, Report Prepared for Food and Agriculture Organisation. FAO: Rome.

World Bank. 2007. World Development Report 2008: Agriculture for Development. Washington, DC: The World Bank. 